\title{
Pembenaran dan Parousia Menurut Paulus
}

\author{
Stepen Untung \\ Institut Agama Kristen Negeri Toraja \\ stepenlucky@gmail.com
}

\begin{abstract}
Abstrak: Pembenaran merupakan hal yang selalu dikaitkan dengan hukum. Pembenaran adalah hal yang sesuai dengan keputusan hakim untuk membenarkan orang yang tidak bersalah. Dalam pandangan Yahudi, pembenaran adalah hal yang harus sesuai dengan hukum Taurat. Parousia merupakan hal yang masih menjadi pertanyaan apakah hal itu akan terjadi. Artikel ini hendak menguraikan mengenai pembenaran dan parousia dalam pandangan rasul Paulus serta hubungan antara pembenaran dan paruosia. Dengan pendekatan kaulitatif kepustakaan untuk memperoleh informasi dan data-data tentang pembenaran dan parousia menurut Paulus. Pembenaran adalah deklarasi Allah. Allah berinisiatif untuk membebaskan manusia yang telah berdosa. Dasar pembenaran adalah melalui kematian Kristus, bukan usaha manusia. Manusia dibenarkan dihadapan Allah oleh karena iman kepada Kristus. Parousia dalam pandangan Paulus adalah hal yang pasti akan terjadi. Kedatangan Tuhan seperti seorang pencuri. Pembenaran juga bersifat eskatologis, berhubungan dengan penghakiman pada saat kedatangan Tuhan yang kedua kalinya (parousia). Allah sendiri yang akan menyatakan umat-Nya benar dihadapan-Nya. Oleh karena itu, Paulus senantiasa untuk mendorong dan memberikan nasihat untuk tetap hidup dalam kekudusan sampai kepada akhir zaman. Pembenaran yang diterima bukan hal yang dijadikan untuk berbuat dosa, tetapi sebaliknya. Dalam menantikan kedatangan Kristus kembali (parousia).
\end{abstract}

Kata Kunci: Pembenaran, Parousia, Yesus Kristus

\begin{abstract}
Absract: Justificatioan is something that is always associated with the law. Justification is a matter according to the juge's decision to justify an innocent person. In the Jewish view, justification is something that must be in accordance with the law. Parousia is something that is still a question of whether it will happen. This article, will describe justification and parousia in the view or the apostle Paul and relationship beetwen justification and parousia. With a qualitative approach to literature to abtain information and data about justification and parousia according to Paul. Justification is God's declaration. God took the initiative to free sinful humans. The basis of justification is trough Christ's death, not human effort. Man is justified before God by faith in Christ. Parousia in Paul's view is something that is sure to happen. The Lord coming is like a thief. Justification is also eschatological, relating to the judgment at the time of the Lord' second coming (parousia). God Himself will declare His people righteous before Him. Therefore, Paul always encourages and gives advice to live in holiness until the end of time. The justification received is not the thing that is made to sin, but vice versa. In waiting for Christ' return (parousia).
\end{abstract}

Keywords: Justification, Parousia, Jesus Christ 


\section{PENDAHULUAN}

Mengenai tentang pembenaran banyak dibicarakan dan istilah pembenaran ini terdapat pemahaman yang berbeda-beda. ${ }^{1}$ Dalam pandangan orang Yahudi, terdapat kesinambungan dari wawasan Perjanjian Lama mengenai pembenaran sebagai sesuatu yang memiliki sangkut paut dengan hukum. Dalam pandangan Yudaisme, kebenaran merupakan hal yang sesuai dengan hukum Taurat. Ketaatan kepada hukum Taurat, hukum Musa yang diberikan melalui tradisi lisan. ${ }^{2}$ Bagi orang Yahudi menjadi sebuah hal yang bertentangan ketika Paulus menyatakan bahwa Allah membenarkan orang yang berdosa dihadapan-Nya. Hal ini menjadi sebuah keputusan yang luar biasa, oleh karena keputusan semacam ini tentu melanggar hal yang normal dan prosedur yang adil bagi seorang hakim. ${ }^{3}$ Pembenaran menurut Westerholm, adalah hal yang sesuai dengan cara hakim, manusia diharapkan bertindak. Hakim akan menjatuhkan hukuman terhadap orang yang salah dan menyatakan kebenaran terhadap orang yang tidak salah. ${ }^{4}$ Orang yang benar adalah orang dinyatakan bebas dari kesalahan oleh hakim. Hal ini merupakan tanggung jawab hakim untuk membenarkan orang yang tidak bersalah dan menghukum orang yang bersalah.

Kedatangan Tuhan yang kedua kalinya adalah hal yang masih menjadi pertanyaan kapankah hal itu akan terjadi. Seperti halnya yang dialami oleh orang-orang di Tesalonika, mengenai tentang kedatangan Tuhan. Paulus dengan tegas meyakinkan jemaat di Tesalonika bahwa kedatangan Tuhan belum terjadi. Mereka terpengaruh oleh beberapa ajaran yang sesat. Namun memang ada tanda-tanda yang akan mendahului hal itu. Bagi orang-orang yang percaya, hal ini akan menjadi pengharapan dan juga hal yang menakutkan bagi mereka yang tidak percaya, sebab akan ada penghukuman yang terjadi. ${ }^{5}$ Dalam penulisan sebelumnya oleh Suyadi Tjhin menguraikan tentang pembenaran dalam konsep Paulus dan Yakobus yang seolah-olah bertentangan. Namun dalam penulisan ini hendak menyajikan tentang pembenaran dan parousia menurut Paulus dan hubungan dari kedua hal tersebut.

\section{METODE PENELITIAN}

Dalam penulisan ini menggunakan metode pendekatan kualitatif. Penelitian studi kepustakaan (library research) dengan mencari informasi dari berbagai sumber pustaka (Jurnal dan buku-buku). Untuk menggali dan memahami lebih dalam tentang konsep pembenaran dan parousia menurut Rasul Paulus.

\section{PEMBAHASAN}

Pada hakikatnya mengenai tentang pembenaran, berasal dari konteks yang selalu berhubungan dengan hukum. Di dalam kalangan Yahudi, pembenaran bersangkut paut dengan hukum atau forensik. Dalam bahasa Yunani pembenaran dapat diartikan dalam beberapa istilah seperti dikaois yang berarti benar atau adil, dikaiosune " kebenaran atau

\footnotetext{
1 . Leon Moris, Teologi Perjanjian Baru (Malang: Gandum Mas, 2014), 93.

2. George Eldon Ladd, Teologi Perjanjian Baru Jilid II (Bandung: Kalam Hidup, 200), 191.

3 . Ibid, 19.

4. Thomas R. Schreiner, New Testament Theology (Yogyakarta: Andi, 2015), 240.

5 . Yanjumseby Yeverson Manafe " Parousia Menurut Paulus" Jurnal Scripta Teologi dan Pelayanan 1, no. 1 ( Mei 2016): 2
} 
keadilan, dikaioma "penghakiman dan dikaioo yang artinya membenarkan. ${ }^{6}$ Di dalam Perjanjian Lama pembenaran dari kata tsedaqa. Kata ini mengandung pengertian yang yuridis atau bersifat forensik oleh karena menyatakan atau mendeklarasikan seseorang benar sesuai dengan tuntutan hukum.

Jadi di dalam Perjanjian Lama, kebenaran merupakan hal yang ada hubungan dengan pribadi. Kebenaran manusia, bersangkut paut dengan hukum. Jadi, jika seseorang yang dinyatakan oleh hakim bahwa ini benar, itu berarti bahwa ia terbebas dan terlepas dari kesalahan. Akan tetapi istilah mengenai pembenaran ini bukanlah satu-satunya arti pembenaran dalam Perjanjian Lama. Istilah dikaioo tidak berarti bahwa membuat menjadi benar akan tetapi dipahami akan tetapi lebih menunjuk kepada menyatakan benar. ${ }^{7}$ Dengan demikian istilah ini tertuju kepada status hukum.

Disisi lain pembenaran ditemukan oleh para ahli didalam gulungan Qumran yang mendekati atau hampir sama dengan apa yang dikemukakan oleh Paulus. Beberapa nats dalam gulungan itu mendukung bahwa kebenaran adalah milik Allah dan bukan milik manusia. Pembenaran hanya oleh karena kebenaran Allah. Dalam hal ini Qumran dan Paulus mengemukakan pemikiran bahwa kebenaran hanya oleh karena anugerah saja (sola gratia). ${ }^{8}$ Jadi dengan demikian, dapat dikatakan mengenai tentang pembenaran merupakan tindakan Allah yang legal artinya bahwa Allah menyatakan seseorang itu benar dengan melalui imannya kepada Yesus. ${ }^{9}$

\section{Pembenaran Menurut Paulus}

Paulus tentu menerima gagasan Ibrani bahwa orang yang benar adalah orang yang berkenan kepada Allah. Akan tetapi Paulus mengembangkan pemahamannya mengenai pembenaran itu. Sehingga dalam pemahamannya, ia mengartikan pembenaran sebagai iman pribadi kepada Yesus Kristus. Jadi, apabila seseorang memiliki iman kepada Kristus, maka tentu ia dinyatakan benar di hadapan Allah. ${ }^{10}$ Pembenaran dalam konsep Paulus, itu berarti bahwa seseorang dibenarkan di dalam pengadilan ilahi disaat pengadilan yang terakhir. ${ }^{11}$ Secara tegas, Paulus menyatakan bahwa manusia adalah orang yang telah berdosa (Roma 3:23) dan oleh karena itu tentu akan menghadapi penghakiman dan Allah sendiri adalah hakim yang adil (II Timotius 4:8). ${ }^{12}$ Dengan demikian, manusia tidak ada jalan untuk keluar dari keadaan demikian. Akan tetapi Paulus dengan jelas menyatakan bahwa Kristus yang telah menyediakan jalan keluarnya. Oleh darah Kristus, manusia dibenarkan. Melalui Kristus, manusia telah dibenarkan secara cuma-cuma oleh kasih karunia karena penebusan di dalam Yesus Kristus. Hal ini berarti bahwa manusia tidak mampu memberikan sumbangsih dalam proses pembenaran. Atau dengan kata lain tidak ada andil manusia dalam pembenaran.

Paulus dalam suratnya kepada jemaat di Korintus menyatakan bahwa mereka telah dibenarkan di dalam Kristus dan di dalam Roh (I Korintus 6:11)". Dalam pernyataan ini

\footnotetext{
6. Donald Guthrie, Teologi Perjanjian Baru 2 (Jakarta: BPK Gunung Mulia, 2016), 123

7. Ibid, 125 .

8. Ibid, 121.

9. Paul Enns, The Moody Handbook of Theology 1 (Malang: SAAT, 2012),117

${ }^{10}$. Donald Guthrie, Teologi Perjanjian Baru 2), 123

11. Thomas R. Schreiner, New Testament Theology, 240

${ }^{12}$. Leon Moris, Teologi Perjanjian Baru, 93.
} 
menunjukkan bahwa pembenaran merupakan deklarasi penghapusan dosa ketika seseorang beriman kepada Yesus Kristus. ${ }^{13}$ Dalam bagian suratnya yang lain Paulus mengatakan bahwa Allah membenarkan orang yang percaya kepada Yesus (Roma 3:26). Ajaran mengenai pembenaran oleh Paulus secara khas terdapat juga dalam Kisah Para Rasul 13:38-39. Menunjukkan bahwa pemberitaan mengenai pembenaran secara vital dikaitkan dengan kehidupan orang-orang percaya. Bagi Paulus, pembenaran dan juga kehidupan dalam Roh, bukan hal yang harus disepelekan. ${ }^{14}$ Dalam hal pembenaran merupakan dasar untuk kehidupan di dalam Roh, dan sukacita oleh karena dibenarkan dengan Allah membebaskan orang-orang percaya untuk menaati Allah.

Dalam surat-suratnya, misalnya dalam Roma, Galatia dan Filipi, Paulus begitu sering mengatakan bahwa manusia dibenarkan oleh iman. Melihat kepada konteks tentang hal ini, terlihat ada pertentangan mengenai kebenaran oleh iman dan kebenaran oleh perbuatan baik. Akan tetapi dalam teks ini Paulus berpendapat bahwa orang yang dinyatakan benar dihadapan Allah bukan orang yang melakukan perbuatan baik, melainkan orang yang percaya. ${ }^{15}$ Hal ini jelas berbeda dari hal yang biasanya. Orang-orang dinyatakan benar dipengadilan berdasarkan sikap baik mereka. Dalam artian bahwa jika melakukan hal baik, akan dinyatakan benar dan jika melakukan hal yang jahat maka akan di hukum.

Dalam kitab Filipi 3:9, kebenaran merujuk pada pemberian Allah. Kebenaran adalah dari Allah, bukan daripada Paulus yang diperoleh karena melakukan Hukum Taurat. Tetapi kebenaran dari Allah yang diperoleh melalui iman kepada Kristus. Kebenaran Allah yang menyelamatkan diberikan kepada manusia sebagai orang yang percaya. ${ }^{16}$ Oleh karenanya, orang-orang percaya dibenarkan oleh pekerjaan Allah melalui Kristus. Dalam persekutuan dengan Kristus orang-orang percaya, telah menerima dan menikmati pembenaran itu di zaman sekarang ini. ${ }^{17}$

Dari hal ini sangat jelas pandangan Paulus mengenai tentang pembenaran. Pertama bahwa oleh karena manusia telah berdosa sehingga tidak bisa untuk keluar dari hal itu, untuk menghadapi pengadilan Allah. Oleh sebab itu, melalui pengorbanan Kristus manusia dibenarkan. Hal kedua, pembenaran hanya melalui karya Kristus. Bukan oleh perbuatan manusia itu sendiri. Melalui penebusan dan pendamaian di dalam Kristus manusia dibenarkan oleh Allah. Ketiga, mengenai pembenaran adalah deklarasi dari Allah sebagai untuk penghapusan dosa manusia. Keempat, pembenaran hanya dapat diperoleh karena iman Jika memiliki iman kepada Kristus atas karya-Nya maka seseorang dinyatakan benar dihadapan Tuhan.

Disisi lain pembenaran juga, harus disertai dengan pengudusan. ${ }^{18}$ Dalam hal ini, keduanya terjadi secara bersamaan namun terdapat perbedaan diantara dua hal ini tetapi tetap bersama-sama. Pembenaran berarti menghapus kesalahan dan dosa sedangkan

${ }^{13}$. Roy B. Zuck \& Darrel L. Bock, A Biblical Theology of The New Testament ( Malang: Gandum Mas, 2011), 317.

${ }^{14}$. Thomas R. Schreiner, New Testament Theology, 241.

15 . Ibid, 243.

16 . Ibid, 245.

17 . Ibid, 248.

18. Suyadi Tjhin “ Ajaran Tentang Pembenaran Menurut Paulus dan Yakobus Serta Signifikansinya Bagi Pemahaman Soteriologi” EFATA: Jurnal Teologi dan Pelayanan 7, no.2 ( Juni 2021): 88. 
pengudusan adalah penghapusan kecemaran dosa dan menuntun orang percaya untuk bertumbuh. Disisi lain pembenaran terjadi diluar diri orang percaya sedangkan pengudusan terjadi didalam diri orang-orang percaya untuk memperbaharui hidup orang percaya. Ketiga bahwa pembenaran adalah hal yang terjadi satu kali untuk selamanya yang dilakukan oleh Kristus. Dan pengudusan itu terjadi secara terus menerus sampai kepada akhir.

\section{Dasar Pembenaran}

Dalam wawasan Yahudi mengenai jasa yang mengarah kepada perbuatan. Oleh sebab itu bagi Paulus pembenaran mempunyai kepentingan yang khusus. Dalam pemahaman orang-orang Yahudi jasa dapat ditabung melalui cara memelihara Hukum Taurat dengan cermat. Dan perbuatan menurut hukum Taurat merupakan jalan keselamatan. ${ }^{19}$ Bagi Paulus ketika ia telah berbalik kepada Kristus, ia menolak mengenai gagasan atau pandangan tentang pembenaran dengan cara melakukan hukum Taurat atau karena hukum Taurat. Oleh sebab itu, dasar pembenaran dikaitkan oleh Paulus dengan kematian Kristus sebagai suatu jalan pendamaian. Oleh karena manusia tidak dapat memperoleh pembenaran melalui dirinya sendiri, maka Allah sendiri telah menyiapkannya. Allah menyediakannya melalui kematian Kristus di kayu salib. Allah sendiri menyediakan persembahan yang diperlukan yaitu Anak-Nya sendiri. Manusia dibenarkan oleh Allah oleh karena Kristus. Tidak ada jasa apapun dari manusia untuk pembenaran dirinya. Didalam karya pendamaian Kristus, Allah membuat manusia yang berdosa menjadi benar. $^{20}$

Pembenaran didasarkan pada kematian Yesus Kristus. Allah berinisiatif memilih dan menentukan Yesus Kristus sebagai jalan pendamaian melalui kematian-nya. Oleh sebab itu dengan jalan demikian, Ia menyatakan keadilan-Nya dalam kematian itu serta menunjukkan kuasa kebenaran-Nya di dalam diri Kristus. ${ }^{21}$ Secara jelas dalam hal ini, Paulus menyatakan bahwa dasar pembenaran adalah melalui kematian Kristus. Namun kematian Kristus yang merupakan dasar bagi pembebasan orang yang berdosa yaitu pembenaran, maka juga ada perlu bukti bahwa hal ini berkenan kepada Allah. Hal yang membuktikan adalah kebangkitan Kristus dari antara orang mati. ${ }^{22}$ Kebangkitan Kritus membuktikan tindakan Allah dalam menampakkan kuasa-Nya dan sekaligus merupakan penampakkan tindakan pembenaran Allah. Kebangkitan menegaskan kodrat Allah yang membenarkan dan disisi lain kebangkitan merupakan suatu ciri yang hakiki hukum dari pembenaran.

\section{Pembenaran, Masa Kini dan Masa Mendatang}

Rasul Paulus dalam berbicara mengenai pembenaran, seperti dalam Roma 5:1,9 dan I Korintus 6:11, pembenaran merupakan hal yang telah terjadi atau sudah selesai. Namun disisi lain, pembenaran bersifat akan datang atau bersifat eskatologis yaitu akan dinyatakan

\footnotetext{
${ }^{19}$. Donald Guthrie, Teologi Perjanjian Baru 2, 127

${ }^{20}$. Ebenhaizer I. Nuban Timo, Allah Menahan Diri, Tetapi Pantang Berdiam Diri ( Jakarta: BPK Gunung Mulia, 2016), 310

21. Herman Ridderbos, Paulus: Pemikiran Utama Theologinya (Surabaya: Momentum, 2015), 169

${ }^{22}$. Donald Guthrie, Teologi Perjanjian Baru 2. 130
} 
pada Hari Penghakiman Terakhir. ${ }^{23}$ Pembenaran seperti yang dinyatakan Paulus juga berbicara mengenai tentang masa depan sebagai suatu deklarasi yang akan dibuat pada saat penghakiman. $^{24}$ Pembenaran merujuk kepada keputusan Allah bahwa seorang tidak bersalah pada hari penghakiman. Keputusan pada akhir zaman disampaikan oleh Allah bagi orang-orang yang percaya kepada Kristus. Setiap orang yang telah dibenarkan melalui darah Kristus, akan diselamatkan dari murka Allah pada masa yang akan datang (eskatologi). Allah sendiri akan menyatakan keputusan tidak bersalah kepada dunia pada hari terakhir. ${ }^{25}$

Dalam pemikiran orang-orang Yahudi, penghakiman yang akan terjadi kelak itu didasarkan pada penilaian perbuatan manusia. Apakah itu memadai atau tidak, sehingga dihantui oleh ketidakpastian, oleh karena tidak seorang yang dapat menyakini bahwa apakah mereka akan diterima oleh Allah atau sebaliknya. Dalam hal demikian pemikiran Paulus pemikiran ini sangat berbeda dalam pemikiran dan pandangannya. Bagi Paulus, orang percaya sudah dibenarkan melalui pekerjaan Kristus. Akan tetapi bagaimana dapat dikatakan bahwa hal ini juga akan dinyatakan pada saat penghakiman. Pembenaran yang sesungguhnya adalah keputusan sudah benar pada saat penghakiman terakhir, dan keputusan itu telah dinyatakan pada masa kini. Bagi orang yang telah percaya, ada keyakinan bahwa tidak ada hal lain yang dialami di masa mendatang daripada hal yang dialami pada masa kini, yaitu pembenaran,

Apabila pembenaran berhubungan dengan penghakiman terakhir, maka tindakan pembenaran itu mencakup segala dosa-dosa seseorang sepanjang hidupnya. Dalam hal ini Paulus menyadari bahwa hal ini akan membawa manusia kepada sikap bertekun dalam dosa. Bagi Paulus, seorang yang percaya tidak akan berbuat demikian. Pembenaran yang memberi jaminan atas pembebasan dari penghukuman bukanlah pendorong dosa, melainkan sebaliknya. Kesadaran seseorang pada masa kini bahwa Allah telah menyatakan benar, pasti akan mencegahnya untuk menyalahgunakan anugerah Allah.

\section{Pembenaran dalam Kitab-Kitab Perjanjian Baru}

Dalam Perjanjian Baru mengenai tentang pembenaran, banyak terdapat di dalam surat-surat Paulus. Akan tetapi pembenaran ini juga terdapat di dalam kitab-kitab yang lain di Perjanjian Baru.

\section{Surat Yakobus}

Secara sepintas, jika melihat surat Yakobus mengenai tentang pembenaraan seolah-olah bertentangan dengan pembenaran yang diungkapkan oleh Paulus. Yakobus menekankan ajarannya untuk dapat mencapai pembenaran adalah melalui perbuatan. ${ }^{26}$ Hal ini terlihat sangat bertentangan dengan ajaran yang diungkapkan oleh Paulus, bukan karena perbuatan tetapi oleh kasih karunia Allah. Namun bila diselidiki akan kedua hal tersebut tidaklah saling bertentangan. ${ }^{27}$ Keprihatinan Yakobus terhadap manusia yang mengaku bahwa

${ }^{23}$. Donald Guthrie, Teologi Perjanjian Baru 2, 129

${ }^{24}$. Roy B. Zuck \& Darrel L. Bock, A Biblical Theology of The New Testament, 317.

${ }^{25}$. Thomas R. Schreiner, New Testament Theology, 241

${ }^{26}$. Donald Guthrie, Teologi Perjanjian Baru 2. 131

27. Ibid, 132 
beriman tetapi tidak menampakkan bukti dari iman mereka yaitu melalui perbuatan baik dan belas kasih. Yang membedakan adalah terletak pada cara penggunaan istilah mereka yang juga dipengaruhi oleh konteks surat yang ditulis. $^{28}$

Yakobus menggunakan istilah perbuatan, dengan maksud bahwa perbuatan yang dilakukan oleh karena memenuhi tuntutan hukum agara dibenarakn, tetapi perbuatan yang dilandasi dan didorong oleh kasih kepada sesama manusia. Dengan demikian, pembenaran yang diungkapkan oleh Yakobus tidak bertentangan dengan Paulus. Dalam suratnya pula Paulus tidak lupa untuk menasihati para pembaca dan penerima suratnya untuk tetap saling mengasihi atau menampakkan kasih persaudaraan. ${ }^{29}$ Namun jika dilihat dari wawasan iman dari kedua penulis, terlihat ada perbedaan tetapi tidak bertentangan. Yakobus secara tegas dalam menyatakan tetang pembenaran dari sudut iman yaitu pengakuan yang lebih mengarah kepada hal yang bersifat akali. Bagi Yakobus sarana pembenaran tidak hanya sebatas pada iman saja tetapi iman yang harus dibuktikan dengan perbuatan. Sedangkan Paulus dalam bahasannya tentang pembenaran menggunakan iman sebagai sebuah penyerahan pribadi. Artinya bahwa seseorang dibenarkan ketika menyerahkan diri kepada Yesus Kristus, ayng merupakan tindakan sebagai suatu pengakuan bahwa tidak ada tempat lain untuk berpijak selain Kristus. ${ }^{30}$

2. Surat-surat Petrus

Dalam suratnya-suratnya, Petrus mengungkapkan bahwa kematian orangorang yang percaya bahwa Kristus telah memikul dosa dan kesalahan manusia adalah hidup di dalam kebenaran. Hal ini menunjukkan bahwa pola manusia yang telah hidup baru harus berlawanan dari dosa dan orang yang telah percaya harus menderita karena kebenaran. Kebenaran juga selalu dihubungkan dengan iman. Pengetahuan tentang kebenaran secara khusus merujuk kepada masa depan, diungkapkan oleh Petrus dalam 2 Petrus 3:13 tentang bumi yang baru dimana terdapat kebenaran. ${ }^{31}$

3. Surat-surat Yohanes

Yohanes dalam surat-suratnya menyatakan bahwa Allah adalah adil dan setia sehingga Ia mengampuni segala dosa dan menyucikannya dari segala kejahatan yang secara harafiah ketidakbenaran. Ada keyakinan bahwa Anak adalah benar yang membawa kepastian bagi orang-orang yang percaya kepadaNya. Dalam hal inilah kebenaran, adalah sebagai bukti kelarihan yang baru. Dan untuk dapat memahami kebenaran, cara terbaik yang dilakukan adalah menghubungkan kebenaran itu dengan proses pengudusan. ${ }^{32}$

\footnotetext{
${ }^{28}$. Donald Guthrie, Teologi Perjanjian Baru 2. 132

${ }^{29}$. Ibid, 132

30. Ibid, 132

31. Ibid, 133

32 . Ibid, 133
} 


\section{Parousia Menurut Paulus}

Secara umum parousia adalah hal yang menyangkut tentang kedatangan Tuhan yang kedua kalinya. Secara asal kata dari bahasa Yunani yaitu parousia sebagai bentuk sederhana dari kata dasar pareimi. Yang memiliki dua pengertian yaitu presence yang berarti kehadiran dan appearing yang berarti penampakan. ${ }^{33}$ Namun parousia adalah istilah yang berkembang dalam kebudayaan Yunani, berkaitan dengan keadaan politik. Dimana merupakan kunjungan dari seorang pejabat atau kaisar terhadap suatu daerah bawahannya atau rakyatnya. ${ }^{34}$ Paulus mengggunakan istilah ini untuk menggambarkan akan kedatangan Tuhan yang sedang dinantikan oleh orang-orang percaya.

Dalam pandangannya tentang parousia, Paulus menyatakan dalam istilah Hari Tuhan, Hari Yesus Kristus. Mengenai tentang kedatangan Tuhan kembali, ia mengemukakan dalam lima pokok ajarannya. Pertama, Kepastian akan kedatangan-Nya kembali. Paulus secara tegas dalam surat-suratnya bahwa Kristus akan datang kembali. Hal ini berarti bahwa kedatangan Tuhan adalah hal yang benar-benar terjadi secara pasti. Kedua, kedatangan Tuhan yang kedua akan selalu ada tanda atau gejala-gejala yang mendahuluinya. Secara khusus dalam suratnya kepada jemaat di Tesalonika, Paulus mengungkapkan beberapa tanda-tanda yang mendahului. Orang-orang akan menjadi murtad. Dalam konteks ini, murtad berarti pemberontakan, dimana peyimpangan dan pengingkaran dari iman. Selain itu akan terdapat orang-orang yang durhaka atau antiKristus. Durhaka dalam hal ini yaitu tidak mengindahkan hukum atau melanggar hukum. Mereka melanggar hukum Allah dan ketidaktaatan kepada perintah Allah. ${ }^{35}$

Ketiga, mengenai sifat kedatangan Kristus kembali. Yesus sendiri telah menggambarkan akan kedatangan-Nya kembali. Datang secara tiba-tiba dan juga tidak disangka. Mengenai hal ini, Paulus juga menyatakannya dalam I Tesalonika 5:2 bahwa kedatangan Tuhan sama seperti seorang pencuri yang berarti secara tiba-tiba dan tan pemberitahuan. Yesus akan datang dengan kemuliaanya. Tidak seperti dalam kedatanganNya yang pertama, kedatangan yang kedua kali Ia akan datang dengan kemuliaan dan keangungan (Ibrani 9:28). Ia datang sebagai raja di atas segala raja dan Tuhan di atas segala tuan. ${ }^{36}$ Keempat, mengenai waktu kedatangan Tuhan. Mengenai waktu kedatanganNya masih menjadi pertanyaan bahwa kapankah Kristus akan datang. Sebelumnya, mengenai tentang sifat kedatangan-Nya kembali secara tidak disangka, itu berarti waktu kedatangan Tuhan kedua kalinya tidak ada yang dapat mengetahuinya namun pasti akan terjadi. Oleh karenanya, yang perlu dilakukan adalah kewaspadaan dan siap siaga. Kedatangan Tuhan yang kedua kali adalah sebuah pengharapan. KedatanganNya yang pertama adalah sukacita, maka kedatangan-Nya yang kedua adalah pengharapan orangorang percaya. ${ }^{37}$

Kelima, kedatangan Yesus yang kedua kalinya tentu akan memiliki tujuan. Dalam tulisannya Paulus mengungkapkan mengenai tujuan kedatangan Yesus yang kedua kalinya.

\footnotetext{
33. Yanjumseby Yeverson Manafe "Parousia Menurut Paulus” Jurnal Scripta Teologi dan Pelayanan 1, no. 1 ( Mei 2016): 3

${ }^{34}$. Warren Carter, Matthew and Empire: A Sociopolitical and Religious Reading (New York: Orbis Books, 2000),39

35. Yanjumseby Yeverson Manafe "Parousia Menurut Paulus" : 5

36. Ibid: 6

37 . Anthony A. Hoekema, Alkitab dan Akhir Zaman (Surabaya: Momentum, 2004), 147.
} 
Dalam I Korintus 15:3 tujuan kedatanganNya adalah untuk membangkitkan orang-orang mati di dalam Kristus. Untuk membawa umat-Nya kembali kepada-Nya dan menghancurkan iblis. Untuk mengadili (I Tesalonika 4:16) dalam hal ini Ia sendiri adalah hakim. Menyatakan apa yang menjadi bagian orang yang percaya dan tidak percaya. ${ }^{38}$ Bagi Paulus, kedatangan Kristus atau hari Tuhan berhubungan dengan penghakiman. Orangorang yang percaya akan diselamatkan dari murka Allah melalui karya Kristus. Oleh sebab itu Paulus senantiasa untuk mendorong dan memberikan nasihatnya di dalam suratsuratnya. Paulus menekankan kualitas hidup moral yang tak bercacat dan tidak bercela. Dalam suratnya ke jemaat di Tesalonika, merupakan tuntutan untuk memperlihatkan moralitas hidup yang dapat dipertanggungjawabkan. ${ }^{39}$

\section{Hubungan Pembenaran dan Parousia}

Pembenaran adalah hal yang bersifat eskatologis. Dalam pengajaran Paulus pembenaran merupakan doktrin eskatologis (akhir zaman, hari kedatangan Tuhan). ${ }^{40}$ Allah adalah pemberi hukum dan hakim yang benar, dan pada hari penghakiman Allah menjatuhkan hukuman dan kebenaran-Nya akan dinyatakan. Keputusan Allah untuk membebaskan dari kesalahan adalah hal yang tidak dapat diganggu gugat oleh siapa pun. Penghakiman pada saat kedatangan Tuhan yang kedua seperti yang diyakini oleh Paulus bahwa terjadi sesuai dengan kebenaran. ${ }^{41}$ Oleh sebabnya untuk dapat terhindari hukuman Allah pada saat kedatangan-Nya yang kedua kalinya, adalah anugerah kebenaran yaitu kebenaran Allah oleh karena iman kepada Yesus bagi orang yang percaya.

Parousia sendiri adalah hal yang menyangkut tentang kedatangan Tuhan yang kedua kalinya atau hal yang berhubungan dengan eskatologis. Dan pembenaran adalah hal yang juga akan terjadi pada akhir zaman. Pada saat kedatangan Kristus yang kedua kali parousia), maka akan terjadi penghakiman atas manusia. Manusia telah berdosa, dan tidak ada lagi kebenaran yang dapat ditemukan pada dirinya. Namun Kristus mengerjakan karya pendamaian dan setiap yang percaya kepadaNya dibenarkan dihadapan Tuhan. Kehidupan manusia yang rusak akibat dosa telah diperbaiki oleh Yesus sehingga statusnya menjadi benar. Oleh karena kematian Kristus, dan dalam pendamian-nya Allah membuat manusia yang berdosa menjadi benar. Sehingga,manusia siap dihakimi pada saat parousia. ${ }^{42}$

Dari hal ini, pembenaran dan parousia saling memiliki keterhubungan. Pertama, bahwa pembenaran selain telah dilaksanakan oleh Kristus, tetapi juga masih bersifat eskatologis atau pada saat kedatangan Tuhan kedua kali. Pada saat penghakiman terakhir tidak ada yang dapat menggugat orang-orang pilihan Allah. ${ }^{43}$ Beberapa orang mungkin akan memberikan dakwaan dihadapan orang-orang pilihan Allah, namun Allah akan menyingkirkan semua dakwaaan itu. Allah sendiri akan menyatakan bahwa umat-Nya

\footnotetext{
${ }^{38}$. Yanjumseby Yeverson Manafe “Parousia Menurut Paulus” Jurnal Scripta Teologi dan Pelayanan 1, no. 1 ( Mei 2016): 8

39. Demianus Nataniel “Parousia, Pembenaran Allah, dan Kebangkitan Orang Mati Menurut SuratSurat Paulus" Jurnal ABDIEL 2, no. 1 (April 2018): 35.

${ }^{40}$. George Eldon Ladd, Teologi Perjanjian Baru Jilid II, 192

${ }^{41}$. Roy B. Zuck \& Darrel L. Bock, A Biblical Theology of The New Testament, 337.

${ }^{42}$. Ebenhaizer I. Nuban Timo, Allah Menahan Diri, Tetapi Pantang Berdiam, 310.

43 . Thomas R. Schreiner, New Testament Theology, 243
} 
berada keadaan yang benar dihadapan-Nya. ${ }^{44}$ Manusia telah memperoleh pembenaran dengan iman kepada Yesus Kristus. Dan dalam hal ini, Allah sendiri yang akan menyatakan umat-Nya adalah benar pada hari penghakiman saat parousia itu terjadi. Itulah sebabnya manusia yang dibenarkan, Paulus menekankan untuk juga tetap hidup dalam kekudusan dan tidak bercacat. Sambil juga menantikan akan kedatangan Tuhan yang kedua kalinya (parousia). Karena disaat itu pembenaran juga akan terjadi.

\section{KESIMPULAN}

Berbicara mengenai tentang pembenaran adalah hal selalu bersifat forensik atau berhubungan dengan proses hukum. Jadi seseorang dinyatakan benar oleh hakim bila sesuai dengan tuntutan hukum. Dalam pemahaman Yudaisme, pembenaran diperoleh oleh karena melaksanakan Hukum Taurat. Artinya keputusan tentang pembenaran sesuai dengan perbuatan mereka. Hal demikian tidak sesuai dengan apa yang diungkapkan oleh Paulus mengenai pembenaran itu sendiri.

Dalam pandangan Paulus, pembenaran adalah deklarasi dari Allah sendiri. Manusia telah jatuh ke dalam dosa dan tidak bisa dengan usaha sendiri untuk keluar dari keberdosaannya. Allah telaha menyediakannya jalan keluar dari hal ini yaitu melalui kematian Yesus Kristus di kayu salib. Oleh sebab itu, Paulus mengatakan bahwa manusia dibenarkan karena iman kepada Kristus. Seorang yang beriman kepada Yesus Kristus dibenarkan di hadapan Allah. Pembenaran dalam hal ini bukan berarti menjadikan benar akan tetapi, menyatakan benar. Pembenaran adalah hal yang dikerjakan oleh Allah diluar manusia. Pembenaran semata-semata dikerjakan di dalam Kristus dengan kata lain Allah menyatakan manusia benar melalui pengorbanan Kristus. Manusia memperoleh kebenaran melalui iman, bukan dengan perbuatan baik atau sesuai tuntutan hukum Taurat. Akan tetapi perbuatan baik adalah bukti dari seseorang yang telah beriman.

Jadi dasar dari pembenaran adalah melalui kematian Kristus. Ini menunjukkan bahwa tidak ada andil atau sumbangsih dalam hal ini. Pembenaran telah dideklarasikan oleh Allah dan telah terjadi akan tetapi juga bersifat eskatologis atau bersifat akan mendatang. Pembenaran merujuk pada keputusan Allah pada hari penghakiman. Allah menyatakan keputusanNya pada akhir zaman atas orang-orang percaya kepada Kristus. Oleh sebab itu, maka pembenaran juga harus disertai dengan pengudusan yang terjadi di dalam diri seseorang secara terus menerus sampai kepada akhir zaman.

Pembenaran dan parousia memiliki hubungan, dimana pembenaran juga akan terjadi pada kedatangan Tuhan yang kedua kalinya . Pada saat ini manusia telah menerima kebenaran di dalam Kristus maka hal itu menjadikan manusia untuk siap dihakimi di hadapan Allah pada saat kedatangan Tuhan yang kedua kalinya. Allah sendiri yang akan menyatakan manusia itu benar pada hari penghakiman. Manusia yang telah menerima pembenaran dan harus senantiasa hidup dalam kekudusan sambil menantikan kedatangan Kristus kembali.

\footnotetext{
${ }^{44}$. Thomas R. Schreiner, New Testament Theology, 243
} 


\section{REFERENSI}

Carter, Warren. Matthew and Empire: A Sociopolitical and Religious Reading. New York: Orbis Books, 2000.

Enns, Paul. The Moody Handbook of Theology 1. Malang: SAAT, 2012.

Guthrie, Donald. Teologi Perjanjian Baru 2. Jakarta: BPK Gunung Mulia, 2016.

Hoekema, Anthony A. Alkitab dan Akhir Zaman. Surabaya: Momentum, 2004.

Ladd, George Eldon. Teologi Perjanjian Baru Jilid II. Bandung: Kalam Hidup, 2002.

Manafe, Yanjumseby Yeverson.“ Parousia Menurut Paulus” Jurnal Scripta Teologi dan Pelayanan 1, no. 1 ( Mei 2016): 1-11.

Moris, Leon. Teologi Perjanjian Baru. Malang: Gandum Mas, 2014.

Nataniel, Demianus. " Parousia, Pembenaran Allah, dan Kebangkitan Orang Mati Menurut Surat-Surat Paulus" Jurnal ABDIEL 2, no. 1 (April 2018): 33-47.

Ridderbos, Herman. Paulus: Pemikiran Utama Theologinya. Surabaya: Momentum, 2015.

Schreiner, Thomas R. New Testament Theology. Yogyakarta: Andi, 2015.

Timo, Ebenhaizer I. Nuban. Allah Menahan Diri, Tetapi Pantang Berdiam Diri. Jakarta: BPK Gunung Mulia, 2016.

Tjhin, Suyadi, "Ajaran Tentang Pembenaran Menurut Paulus dan Yakobus Serta Signifikansinya Bagi Pemahaman Soteriologi” EFATA: Jurnal Teologi dan Pelayanan 7, no.2 ( Juni 2021): 82-93.

Zuck, Roy B. \& Darrel L. Bock. A Biblical Theology of The New Testament. Malang: Gandum Mas, 2011. 